\title{
Military Tribunals and Legal Culture: What a Difference Sixty Years Makes
}

\section{Citation}

Cass R. Sunstein \& Jack L. Goldsmith, Military Tribunals and Legal Culture: What a Difference Sixty Years Makes, 19 Const. Comment. 261 (2002).

\section{Published Version}

http://chicagounbound.uchicago.edu/public_law_and_legal_theory/191/

\section{Permanent link}

http://nrs.harvard.edu/urn-3:HUL.InstRepos:13015052

\section{Terms of Use}

This article was downloaded from Harvard University's DASH repository, and is made available under the terms and conditions applicable to Other Posted Material, as set forth at http:// nrs.harvard.edu/urn-3:HUL.InstRepos:dash.current.terms-of-use\#LAA

\section{Share Your Story}

The Harvard community has made this article openly available.

Please share how this access benefits you. Submit a story.

Accessibility 


\section{University of Chicago Law School Chicago Unbound}

Public Law and Legal Theory Working Papers

Working Papers

2002

\section{Military Tribunals and Legal Culture: What a Difference Sixty Years Makes}

Cass R. Sunstein

Jack L. Goldsmith

Follow this and additional works at: http://chicagounbound.uchicago.edu/ public_law_and_legal_theory

Part of the Law Commons

\section{Recommended Citation}

Cass R. Sunstein \& Jack L. Goldsmith, "Military Tribunals and Legal Culture: What a Difference Sixty Years Makes" (Public Law \& Legal Theory Working Papers No. 27, 2002).

This Working Paper is brought to you for free and open access by the Working Papers at Chicago Unbound. It has been accepted for inclusion in Public Law and Legal Theory Working Papers by an authorized administrator of Chicago Unbound. For more information, please contact unbound@law.uchicago.edu. 


\title{
CHICAGO
}

JOHN M. OLIN LAW \& ECONOMICS WORKING PAPER NO. 153

(2D SERIES)

Public laW AND legal Theory Working Paper No. 27

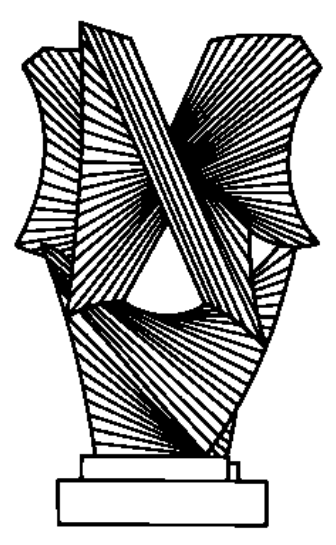

\section{MiLITARY TRIBUNALS AND LEGAL CULTURE: WHAT A DIFFERENCE SIXTY YEARS MAKES}

\author{
Jack Goldsmith and Cass R. Sunstein
}

THE LAW SCHOOL THE UNIVERSITY OF CHICAGO

This paper can be downloaded without charge at the John M. Olin Program in Law and Economics Working Paper Series: http:/www.law.uchicago.edu/Lawecon/index.html and at the

Public Law and Legal Theory Working Paper Series:

http://www.law.uchicago.edu/academics/publiclaw/index.html and

The Social Science Research Network Electronic Paper Collection:

http://ssrn.com/abstract_id=312452 


\title{
Military Tribunals and Legal Culture: What a Difference Sixty Years Makes
}

\author{
Jack Goldsmith $^{*}$ and Cass R. Sunstein ${ }^{* *}$
}

President Bush's Military Order of November 13, 2001 established a legal framework to enable Military Commissions to try terrorists associated with the attacks of September 11, 2001 on Washington, DC, and New York City. ${ }^{1}$ This Military Order was greeted with impassioned criticism in the press, the legal academy, and Congress. But it hardly lacked precedents. Sixty years earlier, in the midst of World War II, President Roosevelt established a Military Commission to try eight Nazi agents who had covertly entered the United States to commit acts of sabotage and terrorism. Although the Nazis failed in their mission, their aims were similar to those of the 9/11 terrorists. And yet Roosevelt's creation of the Commission, and the subsequent secret trial of the Nazi saboteurs, received widespread praise from the same institutions that protested Bush's action.

Our purpose here is not to investigate, except in passing, issues of law and policy. ${ }^{2}$ We instead explore three other questions: What explains the dramatically different reactions? What lessons do the different reactions offer about changes, over time, in the legal culture and in culture in general? What lessons do they offer about the evolution of protections for civil liberties in general and during wartime in particular?

The most tempting, and common, explanation for the different reactions is that there is a significant difference in law - that President Roosevelt's Order stands on much firmer legal ground than President Bush's order. We show that this and related explanations are weak. The different reactions are instead best explained in terms of two large differences between the United States of 1942 and the United States of 2001. In 1942, the nation perceived a far greater threat to its own survival; for this reason Americans were far less solicitous of the interests of defendants thought to have

\footnotetext{
* Professor of Law, University of Chicago

** Karl N. Llewellyn Dist. Service Prof. of Jurisprudence. We thank Dennis Hutchinson, Bernard Meltzer, Eric Posner, Richard Posner, Adrian Vermeule, Detlav Vagts, and G.E. White for helpful comments, and Sarah Rispin for outstanding research assistance.

${ }^{1}$ Technically the reach of the Military Order was somewhat broader than this, see infra __, but the defining cases clearly involved those associated with the September 11 attacks.

${ }^{2}$ The relevant legal issues have been discussed in many places. See, e.g., Neil Katyal and Laurence Tribe, Waging War, Deciding Guilt: Trying the Military Commissions, __ Yale L.J. _ (2002); George Fletcher, War and the Constitution: Bush's Military Tribunals Haven't Got a Legal Leg to Stand On, The American Prospect, Jan. 1, 2002, at 26; Curtis Bradley and Jack Goldsmith, The Constitutional Validity of Military Commissions, 5 Green Bag 2d 249 (2002).
} 
participated in a war effort against the United States. But this explanation is inadequate by itself. It must be supplemented with an understanding of the large-scale, post-1960s shift in American attitudes, involving decreased trust of executive authority and military authority. Our general claim is that with respect to these issues, the legal culture is fundamentally different from what it was before, so much so that many previous practices are barely recognizable. We use the different reactions to the Bush and Roosevelt Military Orders as a way of obtaining a window on this shift.

After making out these claims, we conclude with some general reflections on the evolution of civil liberties protections during wartime. In particular, we identify a mechanism behind the trend toward greater protection for civil liberties during wartime, namely: A judgment, in hindsight, that past civil liberty intrusions were unnecessary or excessive. We also suggest that this trend is, in a way, an accident of America's distinctive history.

\section{The NAZI SABoteurs AND the REACTION to RoOSEVELT's ORDER}

On June 12, 1942, six months after Hitler declared war against the United States, four Nazi agents who had traveled by submarine from France landed in darkness on a beach in Long Island, New York. ${ }^{3}$ A few days later, four more Nazi agents landed on the north Atlantic coast of Florida. The eight men had all lived in America before returning to Germany after Hitler rose to power; two of them, Herbert Haupt and Ernest Burger, were naturalized American citizens. ${ }^{4}$ The saboteurs' mission was the brainchild of Hitler himself, who wanted to cripple U.S. military production capacities and demoralize the American civilian population. Their task was to blow up aluminum plants, railroad lines, canal locks, hydroelectric plants, and bridges. They also had plans for "nuisance bombings" of railroad terminals and Jewish-owned department stores.

Soon after their arrival in the United States, two of the saboteurs, Dasch and Burger, decided to betray their mission to the U.S. government. It is unclear why they turned. Most historians believe they were motivated by fear of betrayal by the other saboteurs, or by fear of detection by U.S. officials. Whatever their reason, Dasch and Burger telephoned the FBI office in New York to announce their plot. When they were dismissed as cranks, Dasch traveled to Washington, where FBI agents took his story more seriously. The FBI interviewed Dasch for five days about the saboteurs' plans, and then rounded up his seven accomplices.

FBI Director J. Edgar Hoover announced the capture of the eight Nazi Saboteurs on June 27. Hoover insinuated that the arrests resulted from the FBI's infiltration of the Nazi system. But he revealed little actual information beyond the names of those involved, how they landed, the weapons they possessed, and their sabotage aims.

\footnotetext{
${ }^{3}$ Unless otherwise indicated, the following account of the Nazi saboteur ordeal is based on Eugene Rachlis, They Came to Kill: The Story of Eight Nazi Saboteurs in America (1961); and David J. Danelski, The

Saboteurs' Case, 1 J S Ct Hist 61 (1996).

${ }^{4}$ Burger, however, had lost his citizenship by virtue of his subsequent enrollment in the German army. See Rachlisat 57 (cited in note 1).
} 
Nonetheless, the nation reacted to the news with enormous joy. "The little that [Hoover] told was enough to make headlines of a size that had hitherto been reserved for the war's major battles. . . . With no information about how the success had been achieved, the public took the news as undeniable proof that Nazi fiendishness was no match for American G-men., ${ }^{5}$

The newspaper reports of the saboteurs' capture insisted that the eight men would face the death penalty. Within the government, however, there was considerable uncertainty about how to prosecute and punish the saboteurs. One complicating factor was that the laws applicable in civilian trials did not permit the death penalty for the nonU.S. citizen defendants. Another was a concern that Article III of the Constitution required the government try the American citizens for treason.

"If there was doubt in the Justice Department, there was none among politicians, the press and most of the public." Almost everyone seemed to call for the saboteurs' execution - the sooner the better. The Washington Post reported that "[d]emands immediately arose among members of Congress for swift justice to the saboteurs - for the death penalty if the law permits it." ${ }^{, 7}$ The general public favored death for the saboteurs by a 10-1 margin. ${ }^{8}$ A Newsweek essay entitled Death for the Saboteurs argued that "we ought to meet this threat with the most swift and ruthless punishment which the law permits." "Life Magazine headlined its story of the capture: The Eight Nazi Saboteurs Should Be Put To Death. ${ }^{10}$

President Roosevelt agreed. "Offenses such as these are probably more serious than any offense in criminal law," he wrote to Attorney General Biddle on June 30. "The death penalty is called for by usage and by the extreme gravity if the war aim and the very existence of our American government. [The saboteurs] should be tried by court martial." 11 Biddle concurred: "A military Commission is preferable because of greater flexibility, its traditional use in cases of this character and its clear power to impose the death penalty." 12

On July 2, Roosevelt issued two proclamations that together established a Military Commission to try the eight saboteurs. One proclamation established the jurisdiction of the Military Commission and purported to preclude judicial review of its decisions. ${ }^{13}$ The

\footnotetext{
${ }^{5}$ Rachlis at $169-70$ (cited in note 1 ).

${ }^{6}$ Rachlis at 173 (cited in note 1 ).

${ }^{7}$ Felix Cotton, Death Penalty Asked for 8 Captured Spies, Wash Post 2 (June 29, 1942).

${ }^{8}$ Contemporary polls, American Institute of Public Opinion, as reported in Week in Review, NYT, Section IV, 2 (Aug 2, 1942).

${ }_{9}^{9}$ Raymond Moley, Perspective: Death for the Saboteurs, Newsweek 64 (July 6, 1942).

${ }^{10}$ As cited in Rachlis (cited in note 1)

${ }^{11}$ FDR Memorandum to Biddle, (June 30, 1942).

${ }^{12}$ Biddle Memorandum to FDR (June 30, 1942).

${ }^{13}$ The proclamation provided that
}

all persons who are subjects, citizens, or residents of any Nation at war with the United States or who give obedience to or act under the direction of any such Nation and who during time of war enter or attempt to enter the United States or any territory or possession thereof, through coastal or 
other named the eight defendants as well as the judges, prosecutors, and defense counsel. It also outlined the structure of the Commission in very general terms. ${ }^{14}$

Roosevelt's announcement that a Military Commission would try the saboteurs "met with general satisfaction in Washington, as it will throughout the country," wrote Lewis Wood, the New York Times Washington correspondent. "The Presidential action calmed the fears of many who realized the delays and technicalities incident to civil trials." ${ }^{\prime 6}$ A few days later, Wood wrote: "Expectations ... that the Administration would seek the death penalty for the Hitler spies before the military commission chosen by the President sounded a heartening note at a moment when indignant Americans everywhere were demanding this extreme punishment for the audacious criminals. Americans wanted to hear the roar of rifles in the hands of a firing squad, and the government had apparently agreed that this is the proper course." 17

The saboteurs' trial began on July 8 on the fifth floor of the Justice Department in a room whose windows were covered in heavy black curtains to block all daylight. Major General Frank McCoy, the Commission's presiding officer, closed the trial to the press and public "due to the nature of the testimony, which involves the security of the United States and the lives of its soldiers, sailors and citizens." "18 McCoy released "communiqués" about the trial that contained adjournment times and other meaningless bits of information. He also let reporters view the empty trial chamber, and he released photographs of the trial and the defendants. But other than this, the trial process took place in complete secrecy.

Although the Washington Press corps complained about this secrecy, ${ }^{19}$ many, and perhaps most, commentators did not object to it. Arthur Krock of the New York Times

\begin{abstract}
boundary defenses, and are charged with committing or attempting or preparing to commit sabotage, espionage, hostile or war-like acts, or violations of the law or war, shall be subject to the law of war and to the jurisdiction of military tribunals; and that such persons shall not be privileged to seek any remedy or maintain any proceeding, directly or indirectly, or to have any such remedy or proceeding sought on their behalf, in the courts of the United States, or of its States, territories, and possessions, except under such regulations as the Attorney General, with the approval of the Secretary of War, may from time to time prescribe.
\end{abstract}

7 Fed. Reg. 5101 (July 2, 1942).

${ }^{14}$ See 7 Fed. Reg. 5103 (July 2, 1942) ("The Commission shall have power to and shall as occasion requires, make such rules for the conduct of the proceedings, consistent with the powers of Military Commissions under the Articles of War, as it shall deem necessary for a full and fair trial of the matters before it. Such evidence shall be admitted as would, in the opinion of the President of the Commission, have probative value to a reasonable man. The concurrence of at least two-thirds of the Members of the Commission present shall be necessary for a conviction or sentence. The record of the trial including any judgment or sentence shall be transmitted directly to me for my action thereon.").

${ }^{15}$ Lewis Wood, Army Court to Try 8 Nazi Saboteurs, NYT 3 (July 3, 1942).

${ }^{16} \mathrm{Id}$.

${ }^{17}$ Lewis Wood, Nazi Saboteurs Face Stern Army Justice, NYT Section IV, 6 (July 5, 1942).

${ }^{18} \mathrm{Id}$.

${ }^{19}$ See Rachlis at 177 (cited in note 1) 
dismissed claims for open press coverage of the trial as "thoughtless." 20 The Nation noted that "[a]lien sabotage trials are obviously rich in information that can be of value to the enemy, particularly to other saboteurs still on the loose." 21 In this light, it viewed the "meaningless communiqués" emerging from the trial as a "victory" for the press.",22

The next piece of real public information about the Commission came three weeks later, when the Supreme Court announced that it would convene a special summer session to entertain the saboteurs' habeas corpus petitions challenging the legality of the military commission. Congress and the public were outraged by the Court's intervention. "The decision to seek recourse in the Supreme Court did not meet popular approval in Washington," reported the New York Times. "On the contrary, there is great dissatisfaction here with the length to which the [three-week military trial] has already proceeded. . . . On all sides hope was expressed that the Supreme Court would make short work of the move." 23 The Los Angeles Times believed that "[s]uch a hearing was totally uncalled for. ... The Supreme Court should never have been dragged into this wartime military matter." 24 The Detroit Free Press agreed: "Realism calls for a stone wall and a firing squad, and not a lot of holier-than-thou eyewash about extending the protection of civil rights to a group that came among us to blast, burn, and kill." 25 So too did the Communist Daily Worker. "The unprecedented action," it said, "is in itself a victory for the enemies of America and the United States.",26

Some newspapers were more supportive. Arthur Krock, who had earlier claimed that the secret military trial was legitimate and fair, saw the Supreme Court's intervention as "a fine service to democracy at war. Whatever disposition the Court shall make of the grave issues presented to it, the fact will brighten the American history of a time when Cicero's apothegm - 'inter arma silent leges ${ }^{27}$ - is the rule in almost every other land.",28 The Washington Post, also a supporter of the military commission, defended Supreme Court review, noting that "the very circumstances that the Court is meeting to hear the petition - this after a long and exhaustive trial of the men by a military commission shows that the saboteurs are being given their day in court." The Post added that "in a time when in so many parts of the world law has become a mockery and justice an obscenity, it will hearten the free men everywhere that here in this citadel of liberty law and justice still function - even for the benefit of those who surreptitiously invaded our land to do us injury.",29

\footnotetext{
${ }^{20}$ Arthur Krock, editorial, In the Nation: When Martial Law Was Proposed for Everybody, NYT 18 (July 14, 1942). See also David Lawrence, Closed Trials of Nazi Spies Held Right, Washington Star, (July 13, 1942) (arguing in favor of closed trials for the saboteurs).

${ }^{21}$ The Nation 41 (July 18, 1942).

${ }^{22} \mathrm{Id}$.

${ }^{23}$ NYT, 8-27.

${ }^{24}$ LA Times, Section II, 4 (July 29, 1942).

${ }^{25}$ As quoted in Rachlis at 249 (cited in note 1).

${ }^{26}$ As quoted in Rachlis at 249 (cited in note 1).

$27^{\circ}$ "In the time of war, the laws are silent".

${ }^{28}$ Arthur Krock, NYT, July 30.

${ }^{29}$ Editorial, Habeus Corpus, Wash Post 12 (July 31, 1942).
} 
On July 31, the Supreme Court announced in a unanimous per curiam order that the military commission was legally constituted and thus that the petitioners' were lawfully detained. The Court did not provide reasons for its conclusion, but indicated that it would do so at a later time.

Most commentators viewed the Court's hurried review of the Commission approvingly. The New York Herald Tribune described the Court's action as a victory for civil liberties:

The action of the Supreme Court was of real importance to the American people as a whole. [The Court] affirmed the right of the President to deny the civil courts of this country to those acting under enemy orders who [violate] the laws of war. In other words, it gave no comfort to the guilty. But by the fact of their intercession the justices of America's highest court reaffirmed to innocent Americans that the law still stands as a shield over them, against malicious usurpation or the quick tempers and brash judgments of wartime. ${ }^{30}$

In all this court drama, American was showing the world that its judicial system could give even an enemy invader a sporting chance to prove his innocence; even in war time we regarded as important the rights of the individual and did not shoot him offhand, as Nazi German would have done. $^{31}$

The Washington Post similarly stated:

In denying civil justice to the eight Nazi saboteurs, the Supreme Court did the expected thing. . . . To handle [the saboteurs] in the civil courts would be to help Hitler immensely, and that would be intolerable. We cannot afford to give our enemy, in our present pass, the slightest assistance. At the same time we are engaged in delivering the world from a tyranny in which the rights of the individual have no place. Those rights are enshrined in our reign of law. If we simply disregard the law, even in our treatment of our enemies, we shall be in danger of coming out of the war as Hitlerian as Hitler. That is why the admittance of the petitions for writs of habeas corpus to the Supreme Court was widely approved. ${ }^{32}$

The Nation was also supportive, though somewhat more impatient:

A touch of the ludicrous is a small price to pay for maintaining the traditions of American judicial procedure. Whatever the fate of the Nazi invaders who landed on our beaches in the middle of June we need not begrudge them a few extra weeks of life involved in giving them a more

\footnotetext{
${ }^{30}$ Editorial, A Welcome Opinion, NYHT 10, (Aug 1, 1942).

${ }^{31}$ Week's News Events: America's Judicial System Tested, NYHT Section II, 3 (August 2, 1942).

${ }^{32}$ Editorial, Saboteur's Case, Wash Post 8 (Aug 1, 1942).
} 
fair trial. The niceties of jurisprudence, however, can be carried too far, and in this case the procedure was beginning to take on such overtones of fantasy that the Supreme Court's refusal to give the defendants standing in the civil courts came in the nick of time. . . . Had the Supreme Court granted [the saboteurs'] petitions, American soldiers would have to go into battle with John Doe summonses in place of rifles and a round of subpoenas in their cartridge belts. But the Supreme Court held firm, and Ringling Brothers need not worry about having to turn Gargantua loose on a writ of habeas corpus. ${ }^{33}$

Unbeknownst to the public, the Military Commission trial ended three days after the Supreme Court announcement, on August 3. The Commission found all eight defendants guilty, recommended that they all be executed, and sent the 3,000-page record to the President for review. On August 8, President Roosevelt publicly announced that he had approved the commission's judgments but had commuted the sentences of Burger and Dasch (the turncoats) to life and thirty years imprisonment, respectively. By the time of the public announcement, the executions had been carried out.

In their post-mortems, the major news organizations praised the Military Commission for its fairness and integrity, the Supreme Court for its quick review and approval of the Commission's legality, and the entire process as a victory for democracy and justice. ${ }^{34}$ The Washington Post's analysis was typical:

Americans will read with grim satisfaction the news that six of the eight Nazi saboteurs have been executed. [. . .] It was hardly surprising, under the circumstances, that many an impatient voice was raised regarding the seeming laggardness of the procedure that was being followed and many an impatient demand was made that the culprits be summarily executed. That certainly was what would have occurred in Germany under similar circumstances. But drum-head trials and summary executions are not the American way. The very enormity of the crime these eight saboteurs had committed made it all the more essential, not for their sake but for ours, that their guilt be established beyond peradventure of a doubt, that they be given the benefit of able counsel, that all the facts be fully reviewed. All this was done. It was bound to take time. Yet actually justice was swift and sure. A month after the military commission first convened the verdict of this distinguished tribunal was carried out. Nothing was lost by this punctilious procedure. But Americans can have the satisfaction of knowing that even in a time of great national peril we did not stoop to the practices of our enemies. And those who may seek to follow in the steps

\footnotetext{
${ }^{33}$ The Nation, 103 (Aug 8, 1942).

${ }^{34}$ Some, to be sure, were critical. Norman Cousins, for example, viewed the trial as "an ostentation out of democratic procedure" that made a "farce out of justice." Norman Cousins, The Saboteurs, Sat Rev of Lit 8 (Aug 8, 1942).
} 
of the eight will be under no illusion as to what is in store for them if they are caught." 35

The New Republic stated that the process revealed that "even in wartime and even toward the enemy we do not abandon our basic protection of individual rights." 36 The New York Herald Tribune, in an editorial entitled "Justice has Been Done," asserted:

No one can suggest that these men, [...] despite the tension of a terrible war, did not receive a full and fair trial. Nor, on the other hand, can it be said that the issue of the trial has jeopardized the safety of the nation. American principles of justice have been vindicated in the eyes of the world. $^{37}$

Even the condemned Nazis acknowledged that they had "been given a fair trial" and that their military lawyers had "represented our case as American officers unbiased, better that we could expect and probably risking the indignation of public opinion." 38

Almost three months after the saboteurs were executed, the Supreme Court released a unanimous opinion - Ex Parte Quirin ${ }^{39}$ - explaining why the Military Commission was constitutionally valid. The Court first interpreted Roosevelt's preclusion of judicial review to permit review on habeas corpus. ${ }^{40}$ It then reasoned that Congress had authorized the use of Military Commissions to try violations of the laws of war, and that at least some of the acts allegedly committed by the defendants constituted such violations. ${ }^{41}$ The Court distinguished a leading Civil War precedent, Ex Parte Milligan, ${ }^{42}$ which had held that a U.S. civilian charged with conspiracy against the federal government could not be tried by a military commission when federal courts were "open to hear criminal accusations and redress grievances." ${ }^{43}$ Quirin held that Milligan involved an individual who was not an enemy belligerent and thus not subject to the laws of war. ${ }^{44}$

The announcement of the Court's opinion in Quirin was reported with little fanfare. We found no editorial commentary about the opinion in any of the mainstream periodicals mentioned above. In the context of the events of late 1942, the decision in Quirin to limit Milligan and to uphold the validity of Roosevelt's military commission was not viewed as a big deal.

\footnotetext{
${ }^{35}$ Editorial, Justice is Done, Wash Post 6 (Aug 8, 1942).

${ }^{36}$ Editorial, The Saboteurs and the Court, New Republic 159 (Aug 10, 1942).

${ }^{37}$ Editorial, Justice Has Been Done, NYHT Section II, 8 (Aug 9, 1942).

${ }^{38}$ See Rachlis at p. 297-98 (cited in n. 1).

39317 US 1 (1942).

${ }^{40} \mathrm{Id}$.

${ }^{41}$ Id at 26-29.

4271 US 2 (1866).

${ }^{43}$ Id at 121-122.

${ }^{44}$ Quirin, 317 US at 45.
} 


\section{9/11 AND THE REACTION TO THE BUSH MILITARY ORDER}

The reaction to President Bush's Military Commission was much different from the reaction to Roosevelt's. The public supported the Bush military commission proposal by a greater than 2-1 margin. ${ }^{45}$ Though significant, this support is more ambiguous and less enthusiastic than the public support Roosevelt received in 1942. But the real differences in reaction were in Congress and especially the mainstream press and members of the legal academy. These institutions reacted with vehement, and sometimes strident, opposition.

The New York Times typified the reaction of many newspapers:

President Bush's plan to use secret military tribunals to try terrorists is a dangerous idea. . . . In his effort to defend America from terrorists, Mr. Bush is eroding the very values and principles he seeks to protect, including the rule of law. The administration's action do[es] an end run around the Constitution. ... [B]y ruling that terrorists fall outside the norms of civilian and military justice, Mr. Bush has taken it upon himself to establish a prosecutorial channel that answers only to him. The decision is an insult to the exquisite balancing of executive, legislative and judicial powers that the framers incorporated into the Constitution. With the flick of a pen, in this case, Mr. Bush has essentially discarded the rulebook of American justice painstakingly assembled over the course of more than two centuries. In the place of fair trials and due process he has substituted a crude and unaccountable system that any dictator would admire. . . . Using secretive military tribunals would ultimately undermine American interests in the Islamic world by casting doubt on the credibility of a verdict against Osama bin Laden and his aides. No amount of spinning by Mr. Bush's public relations team could overcome the impression that the verdict had been dictated before the trial began. Reliance on tribunals would also signal a lack of confidence in the case against the terrorists and in the nation's democratic institutions. ${ }^{46}$

The Times dismissed the Roosevelt precedent for military tribunals as "an embarrassing skirting of the legal process." fashion. $^{48}$

\footnotetext{
${ }^{45}$ In a survey conducted by NPR News, the Kaiser Family Foundation and Harvard University's Kennedy School, 64\% answered "yes," and 26\% answered "no," to the question "Do you favor or oppose military tribunals for non-citizens suspected of terrorism who are captured outside the United States or arrested inside the nation's borders?" See NPR/Kaiser/Kennedy School Poll on Civil Liberties, as reported in NPR, Poll: Security Trumps Civil Liberties (Nov 30, 2001), available online at

<http://www.npr.org/news/specials/civillibertiespoll/011130.poll.html >

${ }^{46}$ Editorial, A Travesty of Justice, NYT A24 (Nov 16, 2001).

${ }^{47}$ See also Editorial, Justice Deformed: War and the Constitution, NYT Section IV, 14 (Dec 2, 2001).

${ }^{48}$ See, e.g., An Un-American Secrecy, LA Times, November 17, 2001, at 24; Editorial, Military Justice (Continued), Washington Post, November 26, 2001, at A24.
} 
Many members of Congress also reacted critically to the Order. Democratic representative Conyers, the ranking member of the House Judiciary Committee, called the order "a civil liberties calamity" that puts "the executive branch in the unattainable role of legislator, prosecutor, judge and jury." ${ }^{49}$ Representative Kucinich described the Bush Order as "Kafka's The Trial writ large," and added that "we should not let the actions of terrorists cause us to reject our American system of justice." ${ }^{, 50}$ Representative Bob Barr, the conservative republican from Georgia, stated the "executive order takes your breath away, if you read the details of it." Bush administration of ignoring "the checks and balances that make up our constitutional framework," adding that it improperly "cut out Congress in determining the appropriate tribunal and procedures to try terrorists," and "sends a terrible message to the world that, when confronted with a serious challenge, we lack confidence in the very institutions we are fighting for." 52

Finally, the legal academy came out strongly against military commissions. Most strikingly, a letter to Senator Leahy, drafted by Yale Law School professors and students, and signed by over 700 law professors and lawyers, claimed that Bush's Order authorized the creation of institutions that were "legally deficient, unnecessary, and unwise." It added that Bush's Military Order "undermines the tradition of separation of powers" because, in contrast to Roosevelt's Commission, which was based on an "express[] grant[]" of legislative authorization, the Bush Order was "without congressional approval." The letter added that "the use of military commissions would be unwise, as it could endanger American lives and complicate U.S. foreign policy." The letter concluded: "The proposal to abandon our existing legal institutions in favor of such a constitutionally questionable endeavor is misguided. Our democracy is at its most resolute when we meet crises with out bedrock ideals intact and unyielding." law professors echoed the same themes in editorials across the country. ${ }^{54}$

\section{WHY THE DIFFERENT REACTIONS?}

The reaction to President Bush's Military Order presents the following puzzle. In 1942, FDR's creation and use of a Military Commission was widely viewed as legitimate, appropriate, constitutionally valid, authorized by Congress, consistent with

\footnotetext{
${ }^{49}$ See Lawmakers Criticize Bush's Order for Military Tribunals, www.cnn.com/ 2001/US/11/16/inv.tribunals.

${ }^{50}$ Press Release of Representative Kucinich, November 15, 2001.

${ }^{51}$ Joyce Howard Price, "Unlikely Allies Fight Federal Anti-Terror Initiatives," Washington Times, November 11, 2001.

${ }^{52}$ George Lardner, Jr., Democrats Blast Order on Tribunals: Senators Told Military Trials Fall Under President's Power, Wash Post A22 (Nov 29, 2001).

${ }_{53}^{53}$ See Yale Letter, http://www.law.yale.edu/yls/c_pages/yls_pa/152/Leahy.pdf.

${ }^{54}$ See, e.g., Bruce Ackerman, Bush Can't Operate as a One-Man Act, LA Times, Dec. 16, 2001, at M5; George Fletcher, War and the Constitution: Bush's Military Tribunals Haven't Gott a Legal Leg to Stand On, The American Prospect, Jan. 1, 2002, at 26; Patricia Williams, War and the Law: The Dangerous Patriot's Game, The Observer, December 2, 2001, at 26; Anne-Marie Slaughter, Al Qaeda Should be Tried Before the World, New York Times, Nov. 17, 2001; Harold Hongju Koh, We Have the Right Courts for Bin Laden, New York Times, November 23, 2001, at A39; Judith Resnick, Invading the Courts, Legal Times, Jan. 14, 2002, at 34 .
} 
American democratic and rule-of-law values, protective of civil liberties, and helpful to the war effort. In 2001, Bush's Military Commission was widely viewed to be illegitimate, inappropriate, unprecedented, unauthorized, unconstitutional, undemocratic, violative of basic civil liberties, harmful to the war effort, and self-defeating. Why were the seemingly similar Military Orders greeted with such different reactions?

\section{A. Unpersuasive Explanations}

We begin with four explanations that have some surface appeal but that cannot, we believe, explain the different reactions to the Roosevelt and Bush Orders.

\section{Domestic Legality}

Many people, including some distinguished professors of law, have argued that Congress granted Roosevelt the authority to establish military commissions to try Nazi saboteurs, while President Bush's order lacked congressional approval. ${ }^{55}$ On this view, the reason for the different reactions lies in significant differences in law. But this is untrue. The Bush Order was premised on the identical congressional statute that was the basis for Roosevelt's Order - the very statute that a unanimous Supreme Court in Quirin held was "explicit[]" congressional authorization for the President to establish military commissions. 56

Some have claimed that the Bush Order, unlike the FDR Order, suspended the writ of habeas corpus. But both Orders used essentially identical language in purporting to preclude judicial review of the commissions. ${ }^{57}$ In the face of the language, the Supreme Court in Quirin interpreted the FDR Order to permit habeas review of the Commission's legality. ${ }^{58}$ By using the same language as the FDR Order, the Bush Order is probably best read to contemplate the same type of habeas review as was exercised in Quirin. $^{59}$

\footnotetext{
${ }_{56}^{55}$ See Yale Letter to Senator Patrick Leahy (cited in note 39).

${ }^{56}$ See Quirin at 28-29 ("By the Articles of War, and especially Article 15, Congress has explicitly provided, so far as it may constitutionally do so, that military tribunals shall have jurisdiction to try offenders or offenses against the law of war in appropriate cases."); id. ("Congress [in Article 15] has authorized trial of offenses against the law of war before such commissions."). .

${ }^{57}$ Both Orders stated that defendants before the Commissions "shall not be privileged to seek any remedy or maintain any proceeding, directly or indirectly, or to have any such remedy or proceeding sought on their behalf, in the courts of the United States." The Roosevelt Order added "except under such regulations as the Attorney General, with the approval of the Secretary of War, may from time to time prescribe," but this provision was never invoked. The Bush Order, unlike the Roosevelt Order, also purported to preclude review in foreign and international courts as well. None of these small differences would explain why the Bush Order was widely criticized for suspending the writ, while Roosevelt's was not.

${ }^{58} 317$ U.S. at 9.

${ }^{59}$ As White House Counsel Alberto Gonzales made clear in an op-ed published in the New York Times. See Alberto R. Gonzales, Martial Justice, Full \& Fair, NYT A27 (Nov 30, 2001) ("The language of the order is similar to the language of a military tribunal order issued by President Franklin Roosevelt that was construed by the Supreme Court to permit habeas corpus review.").
} 
Far from being on more tenuous ground than the Roosevelt Order, one could plausibly argue that the Bush Order is on firmer legal ground in light of the relevant precedents. When Roosevelt created his Military Commission, the leading precedent was Milligan; the Bush Commission, by contrast, could rely on the more recent, more supportive, and probably more relevant Quirin precedent. Because Quirin was on the books when Bush created his Commission but not when Roosevelt created his, Bush's Commission has a stronger grounding in Supreme Court precedent. In addition, although Quirin held that Congress had affirmatively authorized military commissions in Article 15 of the Articles of War, Article 15 is probably best read merely as a congressional refusal to abrogate a prior non-statutory jurisdiction for military commissions. ${ }^{60}$

The Quirin Court may have overreached in concluding that Congress had, at the time of the Quirin decision, authorized the President to establish military commissions. But Congress re-enacted Article 15 in 1950, recodifying it at 10 U.S.C. $\$ 821$ against the background of the Quirin interpretation. The legislative history to this reenacted provision suggests that Congress was aware of, and accepted, Quirin's interpretation of the provision. ${ }^{61}$ And this, in turn, makes it more plausible today than at the time of Quirin that Congress has authorized the President to establish military commissions. Hence the Bush Order has two bases of support that the Roosevelt Order lacked: Quirin itself and a clearer congressional authorization.

Our point here is not to argue that Bush's Order was in fact on firmer legal ground than Roosevelt's. There are other issues that may affect the legality of the two commissions in different ways. ${ }^{62}$ Our point is simply to show that differences in the legality of the two commissions simply cannot explain the differences in reaction to them. In fact, we believe that far from explaining the different reactions to the Roosevelt and Bush orders, the perceived legal differences between the two orders are a product of those different reactions. During World War II, the weaker points in the Executive's position did not receive critical scrutiny, to say the least. By contrast, skepticism about the Bush order resulted in intense concern with the legal technicalities and a high degree of doubt about plausible legal arguments.

2. International Legality

\footnotetext{
${ }^{60}$ See In re Yamashita, 327 U.S. 1, 7 (1946); United States v. Madsen, 343 U.S. 341, 350-55 (1952); see also Testimony of the Judge Advocate General of the Army, General Enoch Crowder, S. Rep. No. 130, 64th Cong. 1st sess. 53 (1916) (in context of Article 15, asserting that military commission "has not been formally authorized by statute," but noting that Article 15 was designed to make clear that the "common law of war jurisdiction was not ousted"); Madsen, 343 U.S. at 353 (referring to General Crowder's testimony concerning Article 15 as "authoritative").

${ }^{61}$ See SEN. RPT. 486, Establishing a Uniform Code of Military Justice, 81st Cong., 1st Sess., at 13 (June 10, 1949) ("The language of [Article of War] 15 has been preserved because it has been construed by the Supreme Court. (Ex Parte Quirin, 317 U.S. 1 (1942)).”); H. REPT. 491, Uniform Code of Military Justice, 81st Cong., 1st Sess., at 17 (April 28, 1949) (same).

${ }^{62}$ For example, Congress declared war in World War II but authorized the war against the al Qaeda terrorists on September 14, 2001. There is a debate about the extent to which a declaration of war is a necessary prerequisite to a military commission. Compare Katyal and Tribe, supra note 2 (arguing that it is a prerequisite) with Bradley and Goldsmith, supra note 2 (arguing that it is not).
} 
Another potentially relevant difference between 1942 and 2002 can be found in international law. In 1955, the United States ratified the 1949 Geneva Conventions on the Protection of Prisoners of War, and in 1991 the United States ratified the International Covenant on Civil and Political Rights ("ICCPR"). Neither of these treaties was in force in 1942; both of them potentially affect the legality of the Bush Military Order under international law. Can the Bush Order's possible illegality under international law explain the differences in reaction?

We doubt it. The severest reactions to the Bush Order, in November and December 2001, were premised on violations of American constitutional and civil liberties traditions, and not on violations of international law. For the most part, the people who criticized Bush's Order were not at the time familiar with the Order's potential international law difficulties. When complaints based on international law arose in early 2002, they did so mostly in connection with the treatment of "detainees" in Guantanamo, not with respect to military commissions. Moreover, it is hard to see how the international law changes affect the validity of the Commissions, as opposed to the procedures the commissions must employ. The Geneva Conventions contemplate the use of military commissions, and thus do not call their legality per se into question. ${ }^{63}$ The ICCPR says nothing about military commissions. While it does guarantee certain basic procedural rights such as the right to choose counsel and be presumed innocent, ${ }^{64}$ it also recognizes that a state party to the treaty may "derogate" from these obligations if it certifies that an emergency affecting the safety of the nation so requires. ${ }^{65}$

\section{FDR v. Bush, Biddle v. Ashcroft.}

FDR was elected in a landslide in 1940; Bush won controversially and lost the popular vote in 2000. Attorney General Biddle was a well-respected establishment figure. Attorney General Ashcroft is not an establishment figure, and indeed he is viewed with suspicion by the left and some on the libertarian right. Relatedly, Roosevelt's government had close ties to the legal establishment (including elites in the legal academy), while Bush does not. In the 1940s, actions by the Executive branch met with a much greater presumption of approval, at least within elite circles. Perhaps there is a kind of heuristic at work in the contemporary reaction. If Bush and Ashcroft are in favor of doing something that might be objectionable from the standpoint of civil liberties, some people might think it reasonable to assume that the action is, in fact, objectionable from that standpoint. A similar heuristic may have been at work in the 1940s. If Roosevelt and Biddle were in favor of doing something that might be objectionable from the standpoint of civil liberties, many people thought it reasonable to assume that the action is not, in fact, objectionable from that standpoint. The heuristic does the work of a more finegrained analysis.

We think that this difference has some explanatory value. Distrust of Bush and Ashcroft by some elites was hardly irrelevant. But the point is insufficient by itself.

\footnotetext{
${ }^{63}$ See Geneva Convention III, Article 84.

${ }^{64}$ See ICCPR, Article 14.

${ }^{65}$ See id., Article 4.
} 
Counterfactuals are notoriously hazardous, but imagine, for example, if a President Gore and his Attorney General (Reno? Tribe?) were responsible for a military order akin to that issued by President Bush. The critical reaction would have been diminished in some circles, but it would have been increased in others. We strongly suspect that it would have been far closer to the reaction to the Bush order than to the Roosevelt order.

\section{The Question of Guilt or Innocence.}

There were many salient differences between the authorizations for the Roosevelt and Bush military commissions. Roosevelt's was much briefer than Bush's. Unlike Bush's, Roosevelt's applied to U.S. citizens; but Roosevelt's had a far narrower substantive scope. It applied only to persons who entered the United States to commit sabotage and related acts. Perhaps most important, Roosevelt's authorization specifically named the eight saboteurs who would be tried by Military Commission. The Bush Order, by contrast, applied not just to al Qaeda members and others who committed terrorist acts against the United States, but also to anyone who "aided or abetted" the commission of terrorist acts or "knowingly harbored" terrorists. And it did not include the names of any persons who would be tried before the Commission.

The important point is that it was clear from the beginning who would be tried before the Roosevelt Military Commission. The defendants were in hand and widely known to be saboteurs; there was no real doubt about their guilt; and their names were included in the set of proclamations establishing the Commission. By contrast, the persons to whom the Bush Order might apply, and their factual guilt, remain uncertain. We speculate that the critical reaction to the Bush Order would have been radically diminished if it applied only to people who were already under arrest for helping to plan the September 11 attack. One of the palpable concerns of the critics is that military commissions might convict the innocent. ${ }^{66}$ There was no serious question about the essential guilt of those tried before Roosevelt's commissions. And there is a psychological point as well: A vivid sense of the identity of the perpetrators could well heighten the sense that an expeditious proceeding is appropriate, and under the right conditions, such a sense could also weaken the protests of those who insist on what they see as procedural requirements.

But again, this cannot be the whole picture. Here as elsewhere, counterfactuals are notoriously hard to assess. But is it plausible to think that military commissions would have been uncontroversial in 2001 and 2002 if the defendants were identified, were in custody, and were widely viewed to be guilty? It might well be that the identification of the perpetrators would, in many circles, have fortified the insistence on the need for an ordinary civil trial. We think that the most important and instructive differences lie elsewhere.

\section{B. Better Explanations}

\footnotetext{
${ }^{66}$ See, for example, Editorial: Military Justice, Wash Post (cited in note 14) (urging that under military tribunals "innocent people likely will be convicted and punished" because "[t]he nature of the rules almost guarantees mistakes").
} 
We now turn to two explanations that we think better account for the differences in reaction in 1942 and 2001.

\section{Differences in War Context.}

The capture of the Nazi saboteurs was one of the first pieces of good news in an unprecedentedly large-scale war that had not gone well during the first half of 1942. The future of the nation was at serious risk, and everyone was aware of that fact. World War II was a "total war" that mobilized the entire nation. Nearly everyone had relatives or friends involved in the fighting, and tens of thousands of Americans had been killed or captured by the summer of 1942. On the home front, there were daily reminders of the war, including rubber shortages, gas rationing, and wage and price controls. Most people had a genuine fear of invasion by the Japanese on the west coast; and on the east coast German submarines had sunk hundreds of ships. Everything was disrupted; all of life was changed. There was no ambiguity about whether the nation was at war, or about whether the nation's survival was at stake.

The events following 9/11 are much different - certainly thus far. 9/11 has required relatively few sacrifices or changes in American life. There is a general (though diminishing) fear among the population. And there have been (relatively minor) disruptions at airports. But we have seen none of the mobilization and sacrifice (or call to sacrifice) that characterized World War II, and the United States has suffered only a comparatively small number of military casualties. The main imperative to the civilian population following 9/11 was not "sacrifice," but rather "spend." Many continue to question whether military action is an appropriate response to 9/11, whether we can truly be at war against non-state actors like al Qaeda, and whether the 9/11 attacks represent a true threat to the nation's survival.

These radical differences in war contexts unquestionably help explain the different reactions to the 1942 and 2001 Military Commission Orders. For those who view the stakes to be lower now than they were perceived to be in 1942, it is altogether natural to question the wisdom of military commissions. Of course it would be extreme to suggest that the nation's prospects for success in World War II would have been seriously compromised by the use of ordinary civil courts. But in 1942, the widespread perception of a threat to national survival made it far harder for people to insist on the use of those courts. For better or for worse, solicitude for the interests of accused belligerents will diminish when the risks to the nation seem most serious and tangible. If the current situation does not seem like a genuine war, then civilian rather than military trials seem more appropriate. If the stakes of the conflict are relatively low, then the justification for diminishing civil liberties and protecting secrets is relatively weak. If 9/11 is not a genuine threat to the nation's survival, then the usual tradeoffs of ordinary civilian trials in which erroneous acquittals are the cost we pay for procedures that diminish the risk of erroneous convictions - seem appropriate. 
Some platitudes are worth repeating: When a nation believes that its future is at risk, it will not be so careful about the protecting the perceived interests of those who are, or who might well be, involving in creating the relevant threat. But here too a cautionary note is appropriate. Suppose that the threat posed by the events of 9/11 were thought to be far greater than they now are. Would military commissions be widely approved? As widely as in 1942? This is doubtful. To be sure, the reaction to military commissions would be more muted if, for example, terrorists exploded a nuclear suitcase bomb, killing 100,000 people. Hence the perception of a lesser threat, in 2001 and 2002, is a contributing factor to the public reaction. But it is hardly all of the picture.

\section{Evolving Social Attitudes: Government, the Military, and Law}

It is not possible to account for the different reactions to the Roosevelt and Bush orders without emphasizing large social and related legal changes within the last sixty years. President Roosevelt acted before Vietnam, before the revelations of Hoover's domestic espionage, and before Watergate. To say the least, this was a time when the press, Congress, and intellectuals had a much higher regard for the Executive branch and the military.

In July 1942, Arthur Krock defended the elaborate secrecy of the Nazi saboteur trial on the following terms: "The FBI vouches for the need of secrecy and the administration's lawyers support the legality of the procedure. Unless these lead to clear abuses, neither is likely to be called into broad question."67 A passage of this sort in the New York Times is unimaginable in 2002. In large part as a result of the disclosures and rebellions of the 1960s and 1970s, Executive branch officers - Democrat or Republican, liberal or conservative - receive diminished levels of trust, at least when there is a plausible claim that civil liberties are at risk. Compare in this regard the frequent suggestion that President Bush's order called for "secret military trials" - a claim that was not supported by the Order itself, which did not mandate secrecy.

But the cultural difference is not adequately described as involving a mere reduction in trust. It involved at the same time a massively strengthened commitment to individual rights, not only within the culture but within the legal system itself. Begin with culture: In 1942, "neither the country, nor its political and intellectual leaders, nor such organizations as the American Civil Liberties Union, were truly libertarian in their outlook." 68 In 1942, restrictions on free speech did not produce a firestorm of protest. Libelous speech was commonly regulated, without discernible public objection. Commercial speech received no protection at all, while sexually explicit speech was heavily controlled, and there was little organized cultural opposition to these practices. Of course this was an era of racial segregation, and public opposition to discrimination was far more tepid than it is today. Nor did the public insist on what we now take to be minimal procedural safeguards for the accused. There is a large question about why, exactly, the culture has shifted in the direction of more solicitude for civil liberties and

\footnotetext{
${ }^{67}$ Arthur Krock, In the Nation: Civil Rights in the Saboteurs' Trial, NYT 18 (July 21, 1942).

${ }^{68}$ See Belknap, supra, at 89. See also Francis Biddle, In Brief Authority 234-35 (Doubleday, 1962); Richard Polenberg, supra, at 38-55.
} 
civil liberties. Undoubtedly World War II itself play a role, encouraging American culture to attempt to distinguish itself radically from those of regimes that did not respect freedom. We cannot fully address the causal question here; but it is clear that the shift has been massive.

Turn now to law: In 1942, federal constitutional law was fundamentally different from what it is today. The Court that wrote Quirin was the same Court that supported the Japanese internment in Hirabayashi and Korematsu. Indigent defendants did not yet have a right to counsel. ${ }^{69}$ The exclusionary rule was yet to be created. ${ }^{70}$ Police abuses had not yet been held to be generally violative of the due process clause of the Fourteenth Amendment. ${ }^{71}$ In fact the criminal procedure revolution was decades away. ${ }^{72}$

In addition, habeas corpus review has changed significantly since 1942. Beginning a few months after Quirin was decided, the Supreme Court began its dramatic extension of habeas corpus from a review of jurisdictional defects in prior judicial proceedings to something closer to appellate review of defendants' constitutional claims. ${ }^{73}$ This expanded conception of habeas was the procedural mechanism that made possible the extraordinary growth, in the late 1950s and 1960s, of constitutional protections for defendants in criminal cases. Although the Rehnquist Court has cut back on the scope of habeas corpus, the writ in its modern guise remains available for properly raised claims of constitutional deprivation. Moreover, the expansion of habeas was not limited to civilian trials. It has also extended to military trials of U.S. service members, even ones held abroad. ${ }^{74}$

Finally, military justice itself has undergone a radical transformation since 1942. Congress's enactment of the Uniform Code of Military Justice ("UCMJ") in 1950 marked "the most important development in military justice since our founding." 75 The Articles of War regime that governed during World War II was a "command-dominated system.. . designed to secure obedience to the commander, and to serve the commander's will.",76 Military justice during this period contained few of the procedural protections of the civilian criminal system, and was widely criticized "harsh and arbitrary."

\footnotetext{
${ }^{69}$ Gideon v. Wainright, 372 U.S. 335 (1963).

${ }^{70}$ Mapp v. Ohio, 367 U.S. 643 (1961).

${ }^{71}$ See Rochin v. California, 342 US 165 (1952).

${ }^{72}$ The largest symbol here is Miranda v. Arizona, 384 US 436 (1966).

${ }^{73}$ See Wainwright v. Sykes, 433 U.S. 72, 79 (1977) (noting that Court in Waley v. Johnston, 316 U.S. 101 (1942), "openly discarded the concept of jurisdiction . . . as a touchstone of the availability of federal habeas review, and acknowledged that such review is available for claims of "disregard of the constitutional rights of the accused, and where the writ is the only effective means of preserving his rights."'). Other important decisions in this line were Brown v. Allen, 344 U.S. 443 (1953); Sanders v. United States, 373 U.S. 1 (1963); Fay v. Noia, 372 U.S. 391 (1963); and Townsend v. Sain, 372 U.S. 293 (1963); see generally Paul Bator, Finality in Criminal Law and Federal Habeas Corpus for State Prisoners, 76 Harv. L. Rev. 441 (1963).

${ }^{74}$ See, e.g., Braden v. $30^{\text {th }}$ Judicial District, 410 U.S. 484 (1973).

${ }^{75}$ General John Cooke, Introduction: Fiftieth Anniversary of the Uniform Code of Military Justice, 165 Mil. L. Rev. 1, 1 (2000).

${ }^{76} \mathrm{Id}$. at 3.

${ }^{77}$ Id. at 6 .
} 
World War II, in which the U.S. military fought to preserve American freedoms, it was widely believed that these freedoms should extend to the military itself.

The UCMJ applied the civilian concept of procedural justice in a way that was consistent with the special circumstances of the military. ${ }^{78}$ The UCMJ and its successor statutes (such as the Military Justice Act of 1968) ${ }^{79}$ established a powerful Court of Military Appeals, independent of command structures, that would eventually extend most conceptions of civilian due process to military courts. The Military Justice Act of 1983 continued this trend by authorizing Supreme Court review of the Court of Military Appeals. Today military justice remains different from civilian justice in important respects. But as Justice Ginsburg correctly noted in Weiss v. United States, "men and women in the Armed Forces do not leave constitutional safeguards behind when they enter military service," for the present system of military justice is "notably more sensitive to due process concerns than the one prevailing through most of our country's history." 80

All of these legal shifts were at least in part a product of the forms of government distrust that we have emphasized. In the radically different legal and social world of 2001, it was much more natural to think that the displacement of civilian courts in favor of a more expeditious military procedure would offend constitutional values. In the past 60 years, the nation has become far more committed to the independence of the federal judiciary and to a high degree of civil liberties and criminal procedural protections.

\section{On The Evolution OF Civil LiBerties During WARTIME}

The different reactions to the Roosevelt and Bush military commissions exemplify a persistent theme in the historical evolution of civil liberties during wartime in the United States. During every serious war in our nation's history, civil liberties have been curtailed. Following (usually not during) each war, elites regret these restrictions on civil liberties because the restrictions often seem - from the ex post perspective when the danger of war has passed and the true extent of the threats become known - to be unwarranted or extreme. During the next war, the perceived abuses during the last war are used as the baseline for determining which civil liberties restrictions are appropriate. This dialectic produces a ratchet effect, over time, in favor of expansive civil liberties during wartime. Of course there is nothing inevitable to this process. We could imagine an opposite effect, in which a failure to provide adequate security was recognized as such, in hindsight, and in which the ratchet effect worked in the opposite direction. But in the American context, with a remarkable record of military success, the historical trend has been toward increasing suspicion of intrusions on civil liberty and civil rights, even when national security seems to be at risk.

Arthur Krock of the New York Times again illustrates the point. In a column on July 13, 1942, Krock recalled a bill proposed by Senator Chamberlin during World War I

\footnotetext{
${ }^{78}$ See generally Jonathan Lurie. Military Justice in America (rev ed. 2001).

${ }^{79}$ Pub. L. No. 90-632, 82 Stat. 1335 (1968).

${ }^{80} 510$ U.S. 163, 194 (1994) (Ginsburg, J., concurring).
} 
to punish spies and disloyalists by court martial. The proposal, Krock noted, came in 1918, when "a wave of hysteria about spies and sabotage has swept the country." bill died after President Wilson opposed it on the ground that it was unconstitutional, inconsistent "with the spirit and practice of American democracy," and in any event unnecessary in light of the Espionage Act and Sabotage Act.

Krock recounted this episode in order to show, in the midst of the saboteurs trial, that "the country seems to have grown up" since 1918 with respect to civil liberties. "No such proposal [like Chamberlin's] or anything remotely like it has been responsibly put forth in Congress or among the public," he noted. He continued:

The chapter from past history confers even greater dignity on the proceedings of the military commission [for the Nazi saboteurs]. The contrast is very great between this deliberate search for truth and justice in a case where more summary methods might easily have been invoked and what Mr. Chamberlain would have done to anyone merely charged with far lesser crimes twenty-four years ago. ${ }^{82}$

From today's perspective, much of Krock's piece seems peculiar. Wilson's favorable invocation in 1918 of the Espionage Act in an argument protective of civil liberties appears ironic, even weird, to the modern observer. For the Espionage Act was amended in May 1918 to include the Sedition Act, a statute that formed the basis of some of the most notorious, and widely regretted, anti-free speech prosecutions in U.S. history. ${ }^{83}$ But the contemporary supporters of the Sedition Act, many of whom viewed themselves as "enlightened liberals" protective of the First Amendment, ${ }^{84}$ were no doubt implicitly comparing their acts to the last great war, in which Lincoln suspended the writ of habeas corpus, arrested civilians and tried them in military commissions, seized newspapers and suspended their mailing privileges, and much more. ${ }^{85}$ Similarly, many today have difficulty understanding how Krock could view a (literally) secret Military Commission as a dignified and deliberate search for truth. But Krock's claim may have seemed natural in 1942, for his implicit baseline of comparison was the World War I experience.

The Krock column illustrates what Chief Justice Rehnquist has described as a "generally ameliorative trend" in civil liberties during wartime. ${ }^{86}$ Rehnquist notes that World Wars I and II were each, by comparison to the prior war, characterized by increased congressional and judicial involvement in the protection of civil liberties, and diminished governmental attempts to suppress criticism of the war effort. ${ }^{87}$ To Rehnquist's catalogue we add the more general point that restrictions of civil liberties

\footnotetext{
${ }^{81}$ Arthur Krock, When Martial Law Was Proposed for Everybody, NYT, July 14, 1942, p. 18.

${ }^{82}$ Id.

${ }^{83}$ See Debs, Sinclair, Abrams, etc.

${ }^{84}$ See Richard Polenburg, Fighting Faiths: The Abrams Case, The Supreme Court, and Free Speech 29-36 (1987).

${ }^{85}$ See generally Mark E. Neely Jr., The Fate of Liberty: Abraham Lincoln and Civil Liberties (1991).

${ }^{86}$ William Rehnquist, All the Laws But One 221 (1997).

${ }^{87}$ Id. at $219-221$.
} 
that came to be regretted after the war were never again repeated. No President has ever repeated Lincoln's suspension of the writ of habeas corpus, his military trials for civilians in the United States, or his brutal suppression of newspapers. We have never again seen loyalty prosecutions as in World War I, and we are unlikely to do so. The same is true of the World War II exclusion of Japanese-Americans.

This brings us back to the Bush Military Commission. Following World War II, many criticized the use of some military commissions during the War, especially the ones in Japan. But the commissions were not condemned with the same intensity as, say, Lincoln's suspension of the writ, or the World War I speech prosecutions, or the Japanese exclusion. In the post-war period, military commissions were not viewed as a horrible "mistake." As we noted above, in 1950 Congress recodified the statute that supported the military trial of the Nazis, and in the process appeared to embrace Quirin's interpretation of affirmative congressional authorization for military commissions. In addition, and in sharp contrast to, say, Korematsu, Quirin has often been cited without embarrassment by the Supreme Court as good law. ${ }^{88}$ In this light, it is perhaps not surprising that the Bush commission, though subject to criticism, was not unthinkable in 2001, and indeed attracted some support among some elites.

It remains to be seen whether a Commission will be used to prosecute those connected to the 9/11 attacks. If they are not, one important reason will be the changed circumstances - including changed legal and cultural circumstances - we have outlined. If commissions are used, they will look far more like civilian courts than past commissions. Department of Defense regulations provide that commission trials are open except when necessary to protect national security or the safety of participants, presume the innocence of the accused, require proof beyond a reasonable doubt, require the prosecutor to provide the accused with access to all evidence to be introduced at trial, including exculpatory evidence, forbid draw adverse inferences from the accused's failure to testify, provide the accused with a military attorney and allow him to choose another attorney, require a 2/3 vote for conviction and a unanimous vote for a death sentence, and require at least two levels of review, including one level that can (but need not) contain civilian judges. ${ }^{89}$ While these procedures fall short of civilian standards (especially with respect to evidence rules, the jury, and judicial review), they are in most respects like military trials under the Uniform Code of Military Justice, and they provide far greater procedural safeguards than any previous military commission, including Nuremberg. These procedural advances can be seen as a result of the factors we have discussed. In short, changes in the use and structure of military commissions fit the general trend we have described.

\footnotetext{
${ }^{88}$ See, e.g., Hohn v. United States, 524 U.S. 236, 245 (1998); Middendorf v. Henry, 425 U.S. 25, 34 (1976); Gosa v. Mayden, 413 U.S. 665, 685 (1972); United States v. O'Brien, 391 U.S. 367, 377 (1968); Reid v. Covert, 354 U.S. 1, 36 n. 68 (1957). By contrast, compare the treatment of Korematsu in, for example, Stenberg v. Carhart, 530 U.S. 914, 952 (2000) (Scalia, J., concurring); Skinner v. Railway Labor Executives' Ass'n, 489 U.S. 602, 635 (1989) (Marshall, J., dissenting); Richmond v. J. A. Croson Co., 488 U.S. 469, 500 (1989).

${ }^{89}$ See http://www.defenselink.mil/news/Mar2002/d20020321ord.pdf.
} 
So too do the other restrictions that the Bush administration has placed on civil liberties. Civil libertarians have condemned the Bush administration's monitoring of attorney-client phone calls, its treatment of the Guantanamo prisoners, and its detention of Muslims on technical immigration violations. We do not express a view on these practices; nothing said here is meant to approve of them, for approval would require a detailed analysis of each. But compared to past wars led by Lincoln, Wilson, and Roosevelt, the Bush administration has diminished relatively few civil liberties. Even a conservative Executive branch, it seems, is influenced by the general trend towards civil liberty protections during wartime.

There is a potential danger here. The danger is that in an age of anthrax, nuclear suitcases, and other easy-to-conceal weapons of mass destruction, the threat posed by al Qaeda and other terrorists might warrant tradeoffs between liberty and security that are inconsistent with ordinary respect for civil liberties. It is always difficult to gauge the seriousness of wartime threats to security in the midst of the war. The problem is significantly exacerbated in the context of asymmetrical warfare involving suicidal terrorists. Whether the government has made the proper tradeoff between liberty and order can be known only ex post. The ameliorative trend in civil liberties is a testament to our extraordinary constitutional traditions and legal culture - and perhaps above all to the post-World War II shift in legal understandings. It is customary, and sensible, to fear that an overestimation of the current threat will lead us to abridge civil liberties in unjustifiable ways. But it is not senseless to fear as well that the gravitational pull of this trend might, in this or other circumstances, lead some to underestimate the threat we actually face.

\section{CONCLUSION}

The different reactions to the Roosevelt and Bush orders illuminate a great deal about the relationship between war and civil liberties, and about cultural and legal change over time. We have argued that perceived legal differences between the orders, far from explaining the different reactions, are a product of those different reactions. The enthusiasm for the Roosevelt order, and the critical reaction to the Bush order, can be explained partly by the much greater perception of threat in 1942 than in 2001 . But the most powerful and instructive explanation, we think, lies in the fact that with respect to actions of the executive branch that might endanger civil liberties, the nation is now far less trusting of government, and far more solicitous of the accused, than it was sixty years ago. This change counts as a genuine revolution not only in law but also in cultural attitudes. An exploration of the radically different social attitudes toward essentially identical legal acts is a remarkable illustration of what has happened. 
Readers with comments should direct them to:

Professor Jack Goldsmith jl-goldsmith@uchicago.edu

Professor Cass R. Sunstein csunstei@midway.uchicago.edu

University of Chicago Law School

1101 East 60th Street

Chicago, IL 60637 


\section{University of Chicago Law School}

\section{Public Law and Legal Theory Working Paper Series}

1. Cass R. Sunstein and Edna Ullmann-Margalit, Second-Order Decisions (November 1999; Ethics, v. 110, no. 1).

2. Joseph Isenbergh, Impeachment and Presidential Immunity from Judicial Process (November 1999; forthcoming Yale Law and Policy Review v.18 \#1).

3. Cass R. Sunstein, Is the Clean Air Act Unconstitutional? (August 1999; Michigan Law Review \#3).

4. Elizabeth Garrett, The Law and Economics of "Informed Voter" Ballot Notations (November 1999, University of Virginia Law Review, v. 85).

5. David A. Strauss, Do Constitutional Amendments Matter? (November 1999)

6. Cass R. Sunstein, Standing for Animals (November 1999)

7. Cass R. Sunstein, Culture and Government Money: A Guide for the Perplexed (April 2000).

8. Emily Buss, Without Peers? The Blind Spot in the Debate over How to Allocate Educational Control between Parent and State (April 2000).

9. David A. Strauss, Common Law, Common Ground, and Jefferson's Principle (June 2000).

10. Curtis A. Bradley and Jack L. Goldsmith, Treaties, Human Rights, and Conditional Consent (May 2000; Pennsylvania Law Review v. 149).

11. Mary Ann Case, Lessons for the Future of Affirmative Action from the Past of the Religion Clauses? (May 2001, Supreme Court Review, 2000)

12. Cass R. Sunstein, Social and Economic Rights? Lessons from South Africa (May, 2000).

13. Jill Elaine Hasday, Parenthood Divided: A Legal History of the Bifurcated Law of Parental Relations

14. Elizabeth Garrett, Institutional Lessons from the 2000 Presidential Election (May 2001).

15. Richard A. Epstein, The Allocation of the Commons: Parking and Stopping on the Commons (August 2001).

16. Jack Goldsmith, The Internet and the Legitimacy of Remote Cross-Border Searches (October 2001).

17. Adrian Vermeule, Does Commerce Clause Review Have Perverse Effects? (October 2001).

18. Cass R. Sunstein, Of Artificial Intelligence and Legal Reasoning (November 2001). 
19. Elizabeth Garrett, The Future of Campaign Finance Reform Laws in the Courts and in Congress, The William J. Brennan Lecture in Constitutional Law (December 2001).

20. Julie Roin, Taxation without Coordination (March 2002).

21. Geoffrey R. Stone, Above the Law: Research Methods, Ethics, and the Law of Privilege (March 2002; forthcoming J. Sociological Methodology 2002).

22. Cass R. Sunstein, Is There a Constitutional Right to Clone? (March 2002).

23. Emily Buss, Parental Rights (May 2002, forthcoming Virginia Law Review).

24. David A. Strauss, Must Like Cases Be Treated Alike? (May 2002).

25. David A. Strauss, The Common Law Genius of the Warren Court (May 2002).

26. Jack Goldsmith and Ryan Goodman, U.S. Civil Litigation and International Terrorism (June 2002).

27. Jack Goldsmith and Cass R. Sunstein, Military Tribunals and Legal Culture: What a Difference Sixty Years Makes (June 2002). 